\title{
精液の果糖産生に対する放射線の影響
}

\author{
弣山大学医学部皮膚科泌尿器科教室 \\ (主任 : 大村順一教授) \\ 雀部 \\ 将

\section{INFLUENCIES ON FRUCTOSE PRODUCTION IN SEMEN BY RADIATION.}

\section{Susumu Sasabe}

From The Department of Urology, Okayama University Medical School.

(Director: Prof. Dr. J. Omura)

I. 緒 言

II. 原爆被爆者の精液果糖ならびに血糖

1. 精液検查法
1）精液採取法
2）精液検査項目
a) 精液量
b) 精子数
c）精液果糖量

2. 血糖定量

3. 検查成績

III.マウス精整腺内果糖濃度並びに血糖值に及ぼす放 射線の影響

1. 実験方法招よび実験材料

2. 実験成績

1）健常マウス

2）マウスに対するX線全身照射の影響 $\mathrm{X}$ 線照射量による影響
A） X線全身照射……1 日後
B）" 3 日後
C ）" 7 日後

X線照射経過日数による影響

D） X線全身照射 $50 \mathrm{r}$

E) " $100 \mathrm{r}$

F) "300r

G) " $\quad 500 \mathrm{r}$

3）マウスに対するX線舅丸照射の影響 $X$ 線照射量による影響
A） X 線辠丸照射……1 日後
B ）" 3 日後
C ）" 7 日後

X線照射経過日数による影響

D） X線睪丸照射 $50 \mathrm{r}$
E ) "100r

F) " $300 \mathrm{r}$

G ) " $\quad 500 \mathrm{r}$

$\mathrm{IV}$. 総括並びに考按

V. 結 論

\section{I 緒 言}

放射線の生体に対する影響に関しては，各方面より種 々研究されつ〉あるが, 近年科学刀発達にともない我々 の接する放射線む，X線のみならず，その使用目的こそ 異れぞも種々の核爆発等にともなう人工放射性物質なぞ 多数存在し，たえずそれらの放射能にさらされていると 考えなければならない，てれに対して原子爆彈被爆以来 とくに放射能の人体に㧤よぼす影響及びその対策, 又は その治療面への應用など, 多くの人々により追求されつ >ある現狀である。しかしながら放射線の殬丸に捛よぼ す影響については原爆以前より幾多の研究が行われてい るが, 男子副性器の活動性, 或は機能については, 未だ まとまつた检索がみられない，と〉において私は，副性 器機能抽よび睪丸の男性ホルモン活動の指針たる精夜果 糖の放射線による影響について检索するととによつてそ の一端を解明せんと志し, 廣島地方に抢ける原子爆彈被 爆者の精液果糖量揖よび, 精液果糖量の消長に密接な関 係があると考えられている血糖値をも同時に測定すると 共に, マウスを使用し, これにX線を照射して, 精囊腺 内果糖を測定し叙上の関係を追求した.

\section{II 原爆被爆者の精液果糖ならびに血糖}

昭和 20 年 8 月廣島に有史最初の原子爆彈が投下されて よりすでに13年を経過するが，原爆の人体に及ぼす影響 に関しては, 被爆直後より今日に及ぶまで, その熱線打 よび放射線なぞによる皮虐, 造血蔵器抢よび性器なぞ身 
体各臟器に及ぼした影響に関し多くの研究が報告されて (いるが(1).2..3).4).5).17).18).，私はその放射能が男子性器の 生理作用にいかなる影響を及ぼしているかについて調查 するため, 被爆者の精液果糖扝よびその果糖量に密接な 関係のある血糖值を測定した．檢查した被爆者は比較的 若く, 被爆距離も短く, 叉泌尿器科的には勿論その他の 身体臟器にも認むべき疾患を有せざる14名を選び測定し た.また同時に精液量および精子数をも檢查した。

1. 精液检查法

1）精液採取法: 禁慾 1 週間の後, 用手法にて滅菌乾 燥せるビーカーに精液を採取せしめ, 約 30 分間室温に放 置して液化するのを待つて检查に供した.

2) 檢查項目

a）精液量：5ccの目盛つきメスピペットで測つた.

b) 精子数: 白血球算定用メランヂュールを用いて精 液を 0.5 目盛まで吸い，さらに Mac. Comber 液を 11 の目盛まで吸い, ょく振盪して赤血球を計算する要領で トーマ・ツァイス血球計算板で最小区劃80個内にある精 子を計算し, その数を $10^{6}$ 倍して $1 \mathrm{cc}$ 中の精子数とした.

c) 精液果糖の定量 : Mannの原法を參照とした呚室 の山村6) の方法汇從つた. 即与(1)精液 $0.4 \mathrm{cc}$ 燐酸緩衝 夜 ( $\mathrm{pH} 7.4$ ) $0.2 \mathrm{cc}$ 加える. (2) との混液 0.1ccをとり, これに $10 \%$ 三塩化醋酸 $3.9 \mathrm{cc}$ 徐从に加え, 後潈過す る. (3)滤液 $2 \mathrm{cc}$ とり，とれに $30 \%$ 塩酸 $7 \mathrm{cc}$ および 0.1 \%レゾルシン氷醋酸溶液 $1 \mathrm{cc}$ 加え, 此の混液を 80 〜 85 ${ }^{\circ} \mathrm{C}$ の温湯中で10分間加温したのち, 流水にて室温に冷却
し, コールマン型光電比色計をもつて比色定量した. フ ィルターの波長は $530 \mathrm{mu}$ である。

2. 血糖定量法 : Folin-Wu の方法によつた. 即ち, スピッツ・グラスに $3.4 \mathrm{cc}$ 蒸溜水をとる. 空腹時. 肘靜 脈より採血せる苳酸塩を加えた血液 $0.2 \mathrm{cc}$ とり，これ を前記蒸溜水中に吹き出し, さらにての蒸溜水を約10司 吸つて吹き出してピペットの内面に附着せる血液を洗 い込みよく混和する。 これに $0.2 \mathrm{cc} の^{2 / 3} \mathrm{~N}$ sulfuric acid を加え，さらに $0.2 \mathrm{cc} の 10 \%$ sodium tungstiate を加えてよく混和し，3〜 5分置き，ついで遠心沈溉し て上清 $2 \mathrm{cc}$ Folin-Wu の sugar tube にとり，これ に2 ccの alkaline copper tartrate を加えて 振晹混和 し, 沸騰水中に 8 分入れた後, 流水にて充分泠却し, こ れに 2 ccの phosphomolybdic acid reagent く振盪混和し，また 5 分間沸騰水に入れた後泠却し，こ れを蒸溜水で12.5ccに均等にうすめ, absorption cell に 入れ，コールマン型光電比色計で測つた. フィルターは 波長 $520 \mathrm{mu}$ 学用いた. かくして附屬の表より血糖値を 算出した。

\section{3. 檢查成績}

実驗の対象とした症例は，18才より38才までの14名で ある. 被爆距離は爆心より最短 $1.5 \mathrm{~km}$ 最長 $3.0 \mathrm{~km}$ て あつた。

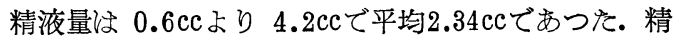
子数は $1 \mathrm{cc}$ 当り 0 より $241 \times 10^{6}$ の間にあり, 平均 145 $\times 10^{6}$ であつた. 精液果糖量は最低 $6 \mathrm{mg} / \mathrm{dl}$ より最高 556.5

第 1 表 原子爆弾被爆者の精液果糖及び血糖值

\begin{tabular}{|c|c|c|c|c|c|c|c|c|}
\hline 番号 & 姓 名 & 年令 & 被爆距離 & 婚・未 & 精 子 数 & 精 液 量 & 精液果糖 & 糖 \\
\hline 1 & N. K. & 21 & $1.5 \mathrm{~km}$ & 末 & $220 \times 10^{6}$ & $3.4 \mathrm{cc}$ & $448 \mathrm{mg} / \mathrm{dl}$ & $80 \mathrm{mg} / \mathrm{dl}$ \\
\hline 2 & T. I. & 38 & 1.5 & 婚 & $241 \times 10^{6}$ & 2.1 & 370 & 80 \\
\hline 3 & N. T. & 27 & 1.7 & 婚 & $0 \times 10^{6}$ & 1.3 & 27 & 59 \\
\hline 4 & S. I. & 22 & 1.8 & 未 & $238 \times 10^{6}$ & 2.0 & 173 & 122 \\
\hline 5 & F. W. & 28 & 1.8 & 未 & $196 \times 10^{6}$ & 0.6 & 74 & 93 \\
\hline 6 & S. M. & 18 & 1.8 & 未 & $198 \times 10^{6}$ & 2.0 & 350 & 114 \\
\hline 7 & Y. T. & 22 & 2.0 & 未 & $290 \times 10^{6}$ & 3.8 & 82 & 68 \\
\hline 8 & $\mathrm{H} . \mathrm{S}$. & 28 & 2.0 & 末 & $141 \times 10^{6}$ & 4.2 & 208 & 131 \\
\hline 9 & K. M. & 26 & 2.2 & 婚 & $44 \times 10^{6}$ & 1.0 & 556.5 & 110 \\
\hline 10 & H. O. & 27 & 2.3 & 未 & $22 \times 10^{6}$ & 3.2 & 304 & 127 \\
\hline 11 & K. T. & 25 & 2.3 & 未 & $158 \times 10^{6}$ & 3.2 & 160 & 84.5 \\
\hline 12 & F. T. & 26 & 2.5 & 未 & $118 \times 10^{6}$ & 2.0 & 134 & 97 \\
\hline 13 & A. M. & 23 & 3.0 & 末 & $132 \times 10^{6}$ & 2.9 & 520 & 114 \\
\hline 14 & T. T. & 28 & 3.0 & 末 & $33 \times 10^{6}$ & 1.0 & 6 & 70 \\
\hline & 平 & & 均 & & $145.1 \times 10^{6}$ & 2.34 & 243.8 & 96.4 \\
\hline
\end{tabular}


$\mathrm{mg} / \mathrm{dl}$ 平均 $243.8 \mathrm{mg} / \mathrm{dl} て ゙$, 血糖值は $59 \mathrm{mg} / \mathrm{dl} よ り ~ 131 \mathrm{mg} / \mathrm{dl}$ 平 均 $96.4 \mathrm{mg} / \mathrm{dl}$ であつた。

被爆距離と精液量および精子数との関係を見るに, と の間に相関々係を見出せず, 又精液果糖括よび血糖值に ついても被爆距離との関係は見出し難く, だ゙血糖値と 精液果糖量とは漂ざ平行関係にあるようにみられた。

この成績を健康人に比するに, 平均值に掞いて精液量 や〉少く, 精子数恃むしろ多く, 果糖濃度に掞いて僅吕 に低値を示した. また血糖值は正常値を示した. しか し，これらの例をくわしく見ると，第 3 例㤝 $1.7 \mathrm{~km} の$ 所で被爆した 27 才の一見健康な既婚者であるが, 精液量 は $1.3 \mathrm{cc}$, 精子は全くみられず, 果糖濃度 $27 \mathrm{mg} / \mathrm{dl}$, 血糖 值も59m//dl 何れも低値を示した. また第 14 例も $3 \mathrm{~km}$ の所で被爆したが, 精液量 $1.0 \mathrm{cc}$, 精子数 $33 \times 10^{6}$, 血 糖值 $70 \mathrm{mg} / \mathrm{dl} て ゙$ 何れも低値を示し, また果糖濃度は $6 \mathrm{mg} / \mathrm{dl}$ と14例中最低値を示した.

昭和 20 年 10 月ょり同年 11 月中旬までの大越3) の調查に よれば, 被爆距離 $8 \mathrm{~km}$ 以内は精子減少の影響あり, 2 $\mathrm{km}$ 以内ではこれを免れないと云う, また $2.6 \mathrm{~km}$ より 不妊症が存在し, $1.6 \mathrm{~km}$ では50\%が不妊, $0.6 \mathrm{~km}$ 以 内では全部不妊であると報告している. また石川 ${ }^{4)}$ の昭 和 21 年 5 月の調查によれば, 原爆による等丸障害のため の精子数異常は, 爆心加 $1.5 \mathrm{~km}$ 以内のものに高度て あるが, それょり遠方のものにも起つていると述べてい る. 又その報告の中に, Schinz によればX線照射の場 合, $34 \%$ HED ( $\fallingdotseq 200 \mathrm{r})$ で一過性去勢を来し， $60 \%$

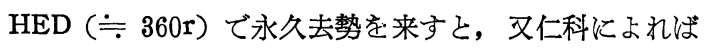
廣島市の場合では, 地上に與えられた爆撃直後の放射能 は,

$\begin{array}{rr}500 \mathrm{~m} \text { 以内 } & 1000 \mathrm{r} \\ 1000 \mathrm{~m} \text { 以内 } & 800 \mathrm{r} \\ 1500 \mathrm{~m} \text { 以内 } & 500 \mathrm{r} \\ 2000 \mathrm{~m} \text { 以内 } & 300 \mathrm{r}\end{array}$

であつたと云うから, Schinz の数字を根握にすれば, $1500 \mathrm{~m}$ 以内のもの永久去勢, また $2000 \mathrm{~m}$ 前後以内のも のは一過性去勢をうけたととになると報告している。し かしながら一方同じ石川 ${ }^{5}$ の 2 年後に打ける昭和 22 年 6 月の調查の報告によれば, 精子数变化注前回より著明に 恢復したと報告している.

廣島原爆障害研究会 7) の報告によれば, 瞬間放射線量 は, 遮蔽が全然なかつた時には, 熱線による中等度の火傷 は爆心より $3 \mathrm{~km}$ ま゙および, $\gamma$ 線と中性子の綜合的な効 果は爆心から約 $2 \mathrm{~km}$ な゙が顯著であると報告している.

被爆後13年を経過した今日, 廣島に括いて被爆せる14
名につき調查した結果, その平均に掞いて, 精子数は正 常値以上であるが, 精液量はや>低值を示し, そのうち $2 \mathrm{cc}$ 以下のものが全体の半数の 7 例学占めている. 精液 果糖濃度は14例中 4 例に低值を認めたが, その外正常 值と考えられる. 血糖值は果糖濃度に低值を示す 4 例の 中, その 3 例に夫々低値を認めた. しかし期待した程の 顯著な影響は認められず，平均値より判断すれば，精子 数, 精液量, 精液果糖拉よび血糖值ともに济ぶ正常範囲 内にあり, 等丸抢よび副性器機能も一隹正常狀態にある ものと考えられる. 然し，第 3 例と第14例の如く顯著な 障害をみとめたもののあるとと沙見逃せない。

\section{III マウス皘坚腺內果糖量並びに血糖值に及ぼす放} 射線の影飡

さきに原子爆彈被爆者の精液果糖並びに血糖値につい て述べたが, これに関連して放射線の精液果糖並びに血 糖值に及法す影響を調べるため次の如き実驗を行つた。

\section{1. 実驗方法招よび実驗材料}

実驗材料としては, 体重11.3〜28.3 g の雄性マウスを 使用し，これを 4 〜 匹艺つに分けて一定の食䬣をもつ て終始飼育観察した. 実驗に際しては予め体重を測定 し, 1 群の平均体重がほぶ一定になる様に心掛けた。また 実驗に当つては 7匹を以て1群とし, 採血またはその他 の手技上の失敗例を除き各群夫タ $5 \sim 6$ 匹它採用した。

放射線としてはX線を使用し，乙れを全身照射群と睪 丸照射群とに 2 大別し, 夫《次の條件にてX線を夫《 50 $\mathrm{r}, 100 \mathrm{r}, 300 \mathrm{r}$, 及び $500 \mathrm{r}$ 包に照射し, 各々共に 1 日，3日，及び 7 日後に実驗に供した。

$\mathrm{X}$ 線照射條件

\begin{tabular}{|c|c|}
\hline 管球電圧 & $100 \mathrm{KV}$ \\
\hline 管球電流 & $3 \mathrm{~mA}$ \\
\hline 滤 過 & $\mathrm{A} L 1 \mathrm{~mm}$ \\
\hline 焦点皮虐距離 & \\
\hline
\end{tabular}

全身照射の場合は照射野は $6 \times 8 \mathrm{~cm}$, 睪丸照射の場合 は厚さ $1.5 \mathrm{~mm}$ の鉛ゴムで身体他部を保護し, 箤丸部のみ に直覀 $1 \mathrm{~cm}$ 丸い穴をあけ，と〉ょり $5 \times 5 \mathrm{~cm}$ 照射野 で箤丸部照射を行つた。

糖側定に際しては, 先づェーテル麻醉のもとに腋蛄動 脈より採血し,血糖測定に供し,ついで開腹して精翼腺孝 前立腺前葉と共に基部に执いて内容液の消失しないよう に充分注意して 1 側の精霟腺を切断し，とれをあらかじ め10\%三塩化醋酸 5 ccを入れておいた秤量摆に投入し, 精霊腺重量を測定し，（10\%三塩化醋酸 5 ccの重量仕計 
算の都合上 $5 \mathrm{~g}$ とした) 次に果糖定量を行つた.

果糖定量は Mann の原法に從つて行つた教室の山 .村6)の方法によつた. しかし著者は精露腺の乾燥するの を防止するため, 又時間的関係をも考慮して 1 园の実驗 は 4〜5匹に止め,つぎの如く行つた. 即ち 1 側の精霊腺 を10\%三塩化醋酸 5 ccを入れた科量壻に投入し, その重 量を測定し，ついでガラス棒で組織を充分に磨りつぶし ながら䁌拌して後滤過する. 滤夜 $2 \mathrm{cc}$ 試驗管にとり, てれに $30 \%$ 塩酸 $7 \mathrm{cc}$ 抢よび $0.1 \%$ レゾルシン氷醋酸 $1 \mathrm{cc}$ を加え, との混液を $80 \sim 85^{\circ} \mathrm{C}$ 温湯中で10分間加温した のち流水で室温に泠却し, コールマン型光電比色計をも つて比色定量する. 波長, $530 \mathrm{mu}$ のフィルターを用い た. 尚精囊腺重量が $150 \mathrm{mg}$ 以上の場合は更に $5 \mathrm{cc} \diamond 10 \%$ 三塩化醋酸を加えて実驗に供した。

血糖定量梳, 前記人体による場合と同様に Folin-Wu の方法により測定した.

\section{2 実驗成績}

1）健常マウス (対照群)

健常マウス 10 匹の 1 側精囊腺重量, 精囊腺の含有せる 果糖量並びに血糖值を測定した成績は第 2 表其の 1 の通 りである.

体重は15〜24gのものを用い, 平均值は19.5 gで, こ れらの平均精囊腺重量は $112.0 \mathrm{mg}$, 果糖濃度は $479.9 \mathrm{mg}$

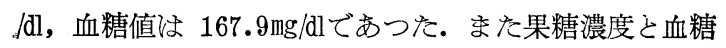
值, 怙よび果糖濃度と精唾腺重量との関係については第 1 圖, 第 2 圖に示卞如くである.

体重13.3 16.0 g の比較的幼若マウス10匹の平均体重 は15.2 gで, これらの平均精襄腺重量は $96.0 \mathrm{mg} て ゙$, 果糖濃 度は42〜 398mg/dl, 平均 $161.4 \mathrm{mg} / \mathrm{dl}$, 血糖値は86〜 179

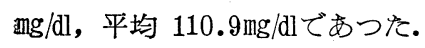

第 2 表（其の 1 ） 正常マウスの果糖濃度

\begin{tabular}{|c|c|c|c|c|}
\hline 番 号 & 体 重 & $\begin{array}{l}\text { 精粠腺 } \\
\text { 重 量 }\end{array}$ & $\begin{array}{ll}\text { 果 } & \text { 糖 } \\
\text { 濃 } & \text { 度 }\end{array}$ & 血糖値 \\
\hline 2 & 15 & 87 & 264 & 86 \\
\hline 3 & 16 & 127 & 398 & 179 \\
\hline 5 & 17 & 96 & 140 & 135 \\
\hline 6 & 18 & 144 & 428.5 & 170 \\
\hline 8 & 19 & 72 & 182 & 172 \\
\hline 11 & 20 & 117 & 628 & 193 \\
\hline 12 & 21 & 109 & 520 & 210.5 \\
\hline 16 & 22 & 102 & 520 & 196 \\
\hline 17 & 23 & 147 & 978 & 179 \\
\hline 19 & 24 & 119 & 740 & 158 \\
\hline 平 均 & 19.5 & 112.0 & 479.9 & 167.9 \\
\hline
\end{tabular}

第 2 表（其の 2 ） 幼若正常マウスの果糖濃度

\begin{tabular}{|c|c|c|c|c|}
\hline 番 号 & 体 重 & $\begin{array}{l}\text { 精露腺 } \\
\text { 重 }\end{array}$ & $\begin{array}{cc}\text { 果 } & \text { 糖 } \\
\text { 濃 } & \text { 度 }\end{array}$ & 血糖値 \\
\hline 1 & 13.3 & 56 & 42 & 92 \\
\hline 2 & 13.9 & 80 & 47.6 & 86 \\
\hline 3 & 14.8 & 86 & 84 & 92 \\
\hline 5 & 15.0 & 87 & 264 & 100 \\
\hline 6 & 15.0 & 107 & 157 & 86 \\
\hline 8 & 15.8 & 101 & 84 & 104 \\
\hline 10 & 15.8 & 97 & 91 & 96 \\
\hline 12 & 16.0 & 117 & 262 & 179 \\
\hline 13 & 16.0 & 102 & 184 & 118 \\
\hline 16 & 16.0 & 127 & 398 & 156 \\
\hline 平 均 & 15.2 & 96.0 & 161.4 & 110.9 \\
\hline
\end{tabular}

第 1 図 正常マゥス: 果糖濃度と血糖值の関係

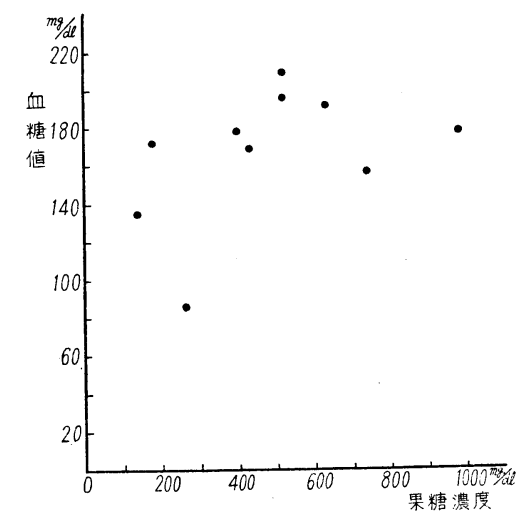

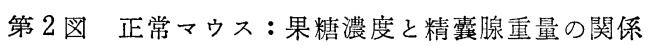

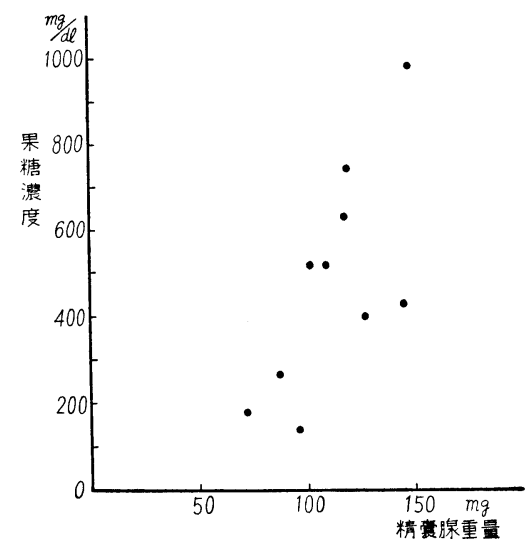

2）マウスに対するX線全身照射の影響

A) X線全身照射 1 日後

体重13.5２2.5 gのマウスを用い，夫々50r，100r， 
第 3 表 $X$ 線全身照射 1 日後

\begin{tabular}{|c|c|c|c|c|c|}
\hline 照射量 & 番号 & 体 重 & $\begin{array}{l}\text { 精軎腺 } \\
\text { 重 量 }\end{array}$ & $\begin{array}{ll}\text { 果 } & \text { 糖 } \\
\text { 濃 } & \text { 度 }\end{array}$ & 血糖値 \\
\hline \multirow{6}{*}{$50 \mathrm{r}$} & 1 & 14.0 & 97 & 74 & 86 \\
\hline & 2 & 15.3 & 107 & 73.5 & 100 \\
\hline & 3 & 19.3 & 217 & 357 & 103 \\
\hline & 4 & 20.0 & 217 & 322 & 122 \\
\hline & 5 & 22.2 & 267 & 378 & 127 \\
\hline & 平均 & 18.2 & 181 & 240.9 & $\overline{107.6}$ \\
\hline \multirow{7}{*}{$100 \mathrm{r}$} & 6 & 15.5 & 105 & 86 & 145 \\
\hline & 7 & 15.8 & 119 & 42 & 100 \\
\hline & 8 & 16.3 & 117 & 84 & 73 \\
\hline & 9 & 21.3 & 217 & 483 & 62 \\
\hline & 10 & 21.3 & 187 & 238 & 80 \\
\hline & 11 & 21.5 & 203 & 330 & 98 \\
\hline & 平均 & 18.6 & 158.0 & 210.5 & 93.0 \\
\hline \multirow{7}{*}{$300 \mathrm{r}$} & 12 & 14.7 & 90 & 42 & 100 \\
\hline & 13 & 16.5 & 102 & 42 & 57 \\
\hline & 14 & 17.3 & 230 & 21 & 65 \\
\hline & 15 & 19.5 & 126 & 314 & 164 \\
\hline & 16 & 21.3 & 195 & 274 & 58 \\
\hline & 17 & 22.5 & 219 & 252 & 77 \\
\hline & 平均 & 18.6 & $\overline{160.3}$ & 157.5 & 86.8 \\
\hline \multirow{7}{*}{$500 \mathrm{r}$} & 18 & 13.5 & 89 & 21 & 101.5 \\
\hline & 19 & 15.3 & 84 & 54 & 170 \\
\hline & 20 & 16.5 & 99 & 21 & 86 \\
\hline & 21 & 19.3 & 90 & 240 & 33 \\
\hline & 22 & 19.8 & 189 & 205 & 33 \\
\hline & 23 & 21.3 & 367 & 210 & 26.5 \\
\hline & 平均 & 17.6 & $\overline{153.0}$ & 125.2 & 75.0 \\
\hline
\end{tabular}

300r，及び 500rを前述の如く夫ふ 1 群 7 匹として照射 した.

その成績は第 3 表，第 3 圖に示す如く精囊腺重量はX 線照射量の増加により殆んど変化を認めないが, 精霬腺 内果糖量はX線照射によりすでに50r 照射より著明に低 下し，X線照射量の増加につれて更に次第に低値を示し た. 血糖値においても果糖量低下と平行して低值を示し た.

\section{B） X線全身照射 3 日後}

体重16.3〜24 gのマウスを用い，夫々50r，100r，300 r 及び 500r を夫く 1 群 7 匹として照射し, 前記同様そ の中の 5 〜 6 匹を採用した。

その成績は第 4 表, 第 4 圖にみるように精囊腺重量は X線照射により殆んど影響をうけないが，精囊腺内果糖 量はX線照射により著明に低下しまたX線照射量の増 加につれて次第に低值を示すのを認めた。 また血糖値に
第 3 図 X 線全身照射 1 日後
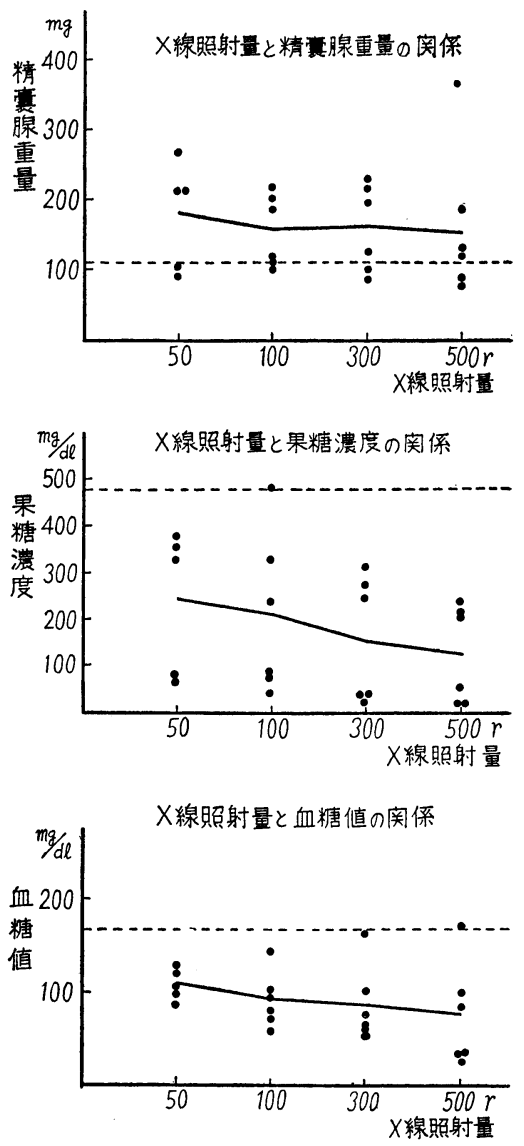

[註] -... 正常平均値

おいても果糖濃度と平行関係にあることを認めた。しか しX線照射量の増加による影響は，精囊腺内果糖も血糖 と共にX線全身照射 1 日後の場合よりも少い. しかも血 糖値においては照射 $\mathrm{X}$ 線量増加により低下の傾向は示す が大体正常值範囲内である.

C) X線全身照射 7 日後

$\mathrm{X}$ 線照射後の衰弱を考えて特に19.3〜28.3 g の重量を 有する大きなマウスを用い，X線全身照射 1 日後及び 3 日後の場合と同様に夫々50r，100r，300r 及び 500r を 1 包に照射した. 照射後7 日間を経過してもマウスに外 見上特別の変化は見られなかつた。

精囊腺重量は第 5 表，第 5 圖にみるようにX線照射量 による影響は殆んご認められず，精囊腺内果糖濃度掞よ び血糖値は，X線全身照射 3 日後と同様にX線照射によ り夫々低值を示し，X線照射量の増加と共に低下の㑯向 
第 4 表 $X$ 線全身昭射 3 日後

\begin{tabular}{|c|c|c|c|c|c|}
\hline 照射量 & 番号 & 体 重 & $\begin{array}{l}\text { 精軎腺 } \\
\text { 量 }\end{array}$ & $\begin{array}{ll}\text { 果 } & \text { 糖 } \\
\text { 濃 } & \text { 度 }\end{array}$ & 血糖值 \\
\hline \multirow{6}{*}{$50 \mathrm{r}$} & 1 & 18.3 & 129 & 197.5 & 164 \\
\hline & 2 & 21.3 & 117 & 227 & 174 \\
\hline & 3 & 22.3 & 98 & 260 & 199 \\
\hline & 4 & 22.8 & 152 & 201 & 164 \\
\hline & 5 & 23.3 & 177 & 590 & 151 \\
\hline & 平均 & 21.6 & 134.6 & 295.1 & 170.4 \\
\hline \multirow{6}{*}{$100 \mathrm{r}$} & 6 & 17.4 & 11.7 & 274 & 160 \\
\hline & 7 & 22.8 & 131 & 274 & 139 \\
\hline & 8 & 23.3 & 127 & 224 & 147 \\
\hline & 9 & 23.6 & 160 & 404 & 164 \\
\hline & 10 & 24.0 & 107 & 248 & 193 \\
\hline & 平均 & 22.2 & 128.4 & 284.8 & 160.6 \\
\hline \multirow{6}{*}{$300 \mathrm{r}$} & 11 & 16.3 & 101 & 98 & 188 \\
\hline & 12 & 20.3 & 111 & 114 & 156 \\
\hline & 13 & 20.8 & 129 & 264 & 124 \\
\hline & 14 & 21.2 & 146 & 556 & 170 \\
\hline & 15 & 21.8 & 94 & 140 & 151 \\
\hline & 平均 & 20.1 & $\overline{116.2}$ & 234.4 & 157.8 \\
\hline \multirow{6}{*}{$500 \mathrm{r}$} & 16 & 17.3 & 99 & 98 & 181.5 \\
\hline & 17 & 18.5 & 92 & 120 & 70 \\
\hline & 18 & 20.3 & 128 & 187 & 135 \\
\hline & 19 & 20.3 & 115 & 150 & 135 \\
\hline & 20 & 21.3 & 129 & 296 & 170 \\
\hline & 平均 & 19.5 & 112.6 & 170.2 & 138 \\
\hline
\end{tabular}

ね示したが，その影響は照射 3 日後の場合より少いよう である. 血糖値についてはX線照射量の増加により低下 の傾向は示すが，その影響は非常に少い。

次にX線を夫ぬ全身に50r，100r，300r及び500r照 射した各群について，その経過日数による影響を観察し た. この場合体重を一定させるために特に20 g 以上のマ ウスのみを集めた。

D） X線全身照射 $50 \mathrm{r}$

第 6 圖のように精囊腺重量は 3 日後に扮いて 1 日後よ りは低下し，7 日後にはや>恢復の徵が見られる. 果糖 濃度は 1 日後より著明に減少し， 3 日後は更に減少する も，7 日後には殆んざ恢復する. 血糖值は 1 日後は低值 を示すも 3 日後より㤝恢復の徵を示し，7 日後には殆ん ぞ正常值に帰る.

E） X線全身照射 $100 \mathrm{r}$

第 7 圖の如く精囊腺重量汇全身照射 100r の場合も, 50r 照射の場合と同様に 3 日後には 1 日後よりもやや低 下し，7 日後にはや>恢復し，果糖濃度も50r 照射の場
第 4 図 $X$ 線全身照射 3 日後
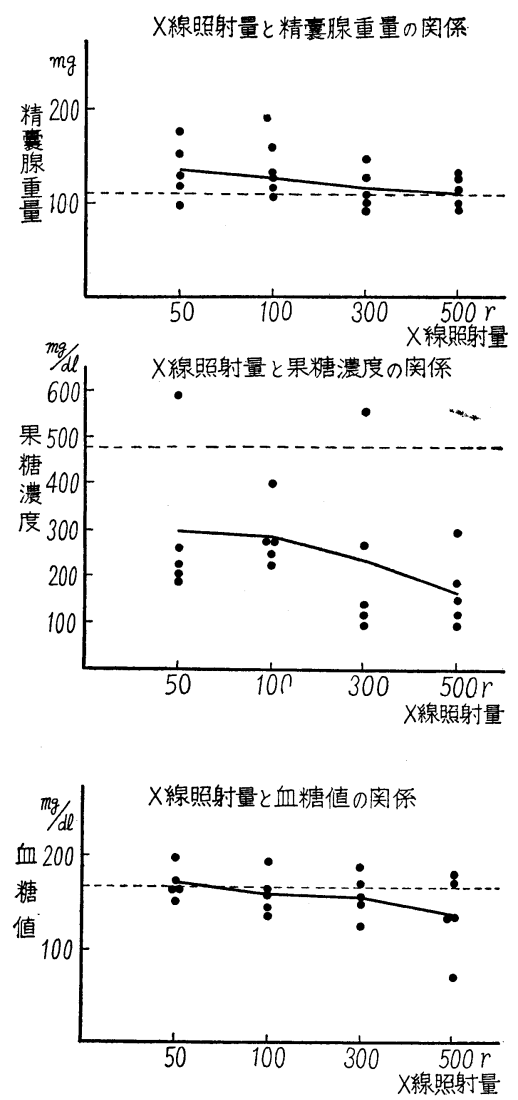

[註]--.- 正常平均值

合と同様に 1 日後より著明に低下し， 3 日後は更に低下 するが，7 日後には殆んぞ恢復する.血糖值についても50 r 照射の場合とほぶ同じょうな傾向を示すが，50r 照射 の場合よりも照射後 1 日の血糖值は更に低值を示した.

F) X線全身照射 $300 \mathrm{r}$

精糞腺重量, 精霊腺内果糖濃度掞よび血糖値のいづれ もが50r 及び 100r 照射の場合と同様の傾向を示すが， 何れも 7 日後に招ける恢復がや>惡い.

G） X線全身照射 500r

X線照射量が 1 四に 500r の大量になつてもマウスの 全身狀態には何等外見上の変化はなく, 精囊腺重量, 精 賈腺内果糖濃度おょび血糖值の何れも，50r，100r及び 300r 全身照射の場合と同様の傾向を示した.

3） マウスに対するX線粹丸照射の影響

A) X線睪丸照射 1 日後

体重13.8 20.0 gのマウスを用い，全身照射の場合と 
第 5 表 $X$ 線全身照射 7 日後

\begin{tabular}{|c|c|c|c|c|c|}
\hline 照射量 & 番号 & 体 重 & $\begin{array}{l}\text { 精轅腺 } \\
\text { 量 }\end{array}$ & $\begin{array}{ll}\text { 果 } & \text { 糖 } \\
\text { 濃 } & \text { 度 }\end{array}$ & 血糖値 \\
\hline \multirow{6}{*}{$50 \mathrm{r}$} & 1 & 21.8 & 133 & 422 & 203 \\
\hline & 2 & 23.8 & 150 & 668 & 164 \\
\hline & 3 & 24.9 & 129 & 334 & 196 \\
\hline & 4 & 26.7 & 165 & 534 & 174 \\
\hline & 5 & 27.5 & 172 & 668 & 179 \\
\hline & 平均 & 24.9 & 149.8 & 525.2 & $\overline{183.2}$ \\
\hline \multirow{6}{*}{$100 \mathrm{r}$} & 6 & 22.1 & 110 & 364 & 174 \\
\hline & 7 & 22.3 & 147 & 570 & 147 \\
\hline & 8 & 22.8 & 191 & 652 & 199 \\
\hline & 9 & 25.0 & 172 & 416 & 188 \\
\hline & 10 & 25.6 & 176 & 564 & 203 \\
\hline & 平均 & 23.6 & $\overline{159.2}$ & $\overline{513.2}$ & $\overline{182.2}$ \\
\hline \multirow{6}{*}{$300 r$} & 11 & 21.3 & 121 & 282 & 127 \\
\hline & 12 & 23.3 & 133 & 31.4 & 188 \\
\hline & 13 & 23.4 & 125 & 386 & 208 \\
\hline & 14 & 25.3 & 121 & 504 & 179 \\
\hline & 15 & 25.3 & 162 & 572 & 167 \\
\hline & 平均 & 23.7 & 132.4 & 411.6 & $\begin{array}{l}173.8 \\
\end{array}$ \\
\hline \multirow{6}{*}{$500 \mathrm{r}$} & 16 & 19.3 & 102 & 230 & 116 \\
\hline & 17 & 20.0 & 124 & 182 & 184 \\
\hline & 18 & 20.3 & 121 & 354 & 160 \\
\hline & 19 & 24.5 & 157 & 772 & 172 \\
\hline & 20 & 28.3 & 154 & 474 & 160 \\
\hline & 平均 & 22.5 & 131.6 & $\mid 402.4$ & 158.4 \\
\hline
\end{tabular}

同様に，夫ふ50r，100r，300r および $500 \mathrm{r}$ を夫々 1 群のマウスに照射した.

精囊腺重量はX線照射量の増加により殆んど变化な く, 精囊腺内果糖濃度はX線照射により,すでに50r て 低下を見るが，100r では更に低下し，300r ではヌや

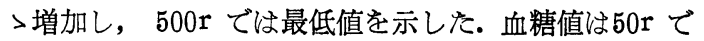
は㴽ざ正常值を示すが，X線照射量の增加につれて 100 r より更に 300r，300rより更に 500r 照射群と徐々で はあるが増加の傾向を示した。

\section{B）X線睪丸照射 3 日後}

体重11.3 24.8 gのマウスを用い，夫ふ50r，100r， 300r 及び 500 rを夫々 1 群に照射した。精囊腺重量は 50r 及び 100r では殆んど变化はないが，300r 及び 500r 照射によりや>低値を示した。精囊腺内果糖濃度 は50r 照射では殆んぞ正常平均值の $1 / 4$ 值を示すが， 100 r ではや>恢復し，300r 及び 500r では 100r 照射の 時より刃や〉低值を示した。血糖值は50r 照射で，精囊 腺内果糖と同様に最低值を示したが，100r，300r及び
第 5 因 X線全身照射 7 日後
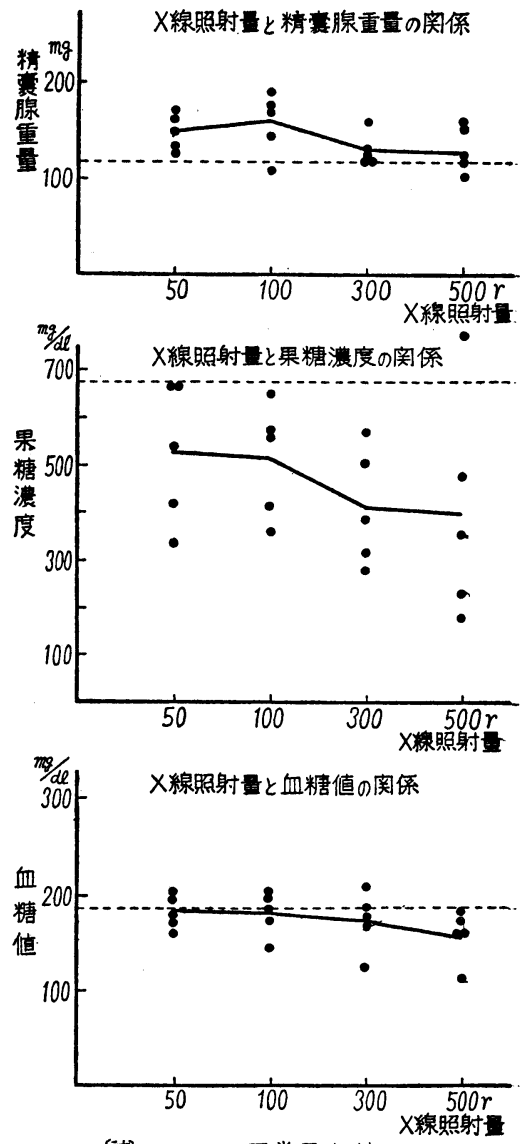

謿 …- 正常平均値

500r ではほぼ正常值に近くなり，血糖值は果糖濃度に゙ 平行して增減しているょうである.

C） X線等丸照射 7 日後

体重12.8 27.8 gのマウスを用い，X線悬丸照射 1 日 後及び 3 日後同様に，50r，100r，300r 及び500r 照射した。

精壤腺重量はX線照射 7 日後においては, X線照射量 による影響は全く認められず，精賈腺内果糖濃度は50r ですでに低下を示し，100r，300r とX線照射量の増加 により次第に低值を示し, 300r 照射時が最低值を示し た. $500 \mathrm{r}$ 照射群では 300r 照射群よりかえつて高値を 示した. これは $300 \mathrm{r}$ 照射群のマウスの平均体重が最低 のためとも考えられる. 血糖值は殆んごX線照射量によ る影響は見られなかった。

X線を箤丸に夫々 $50 \mathrm{r}, 100 \mathrm{r}, 300 \mathrm{r}$ 及び $500 \mathrm{r}$ 照射せ 

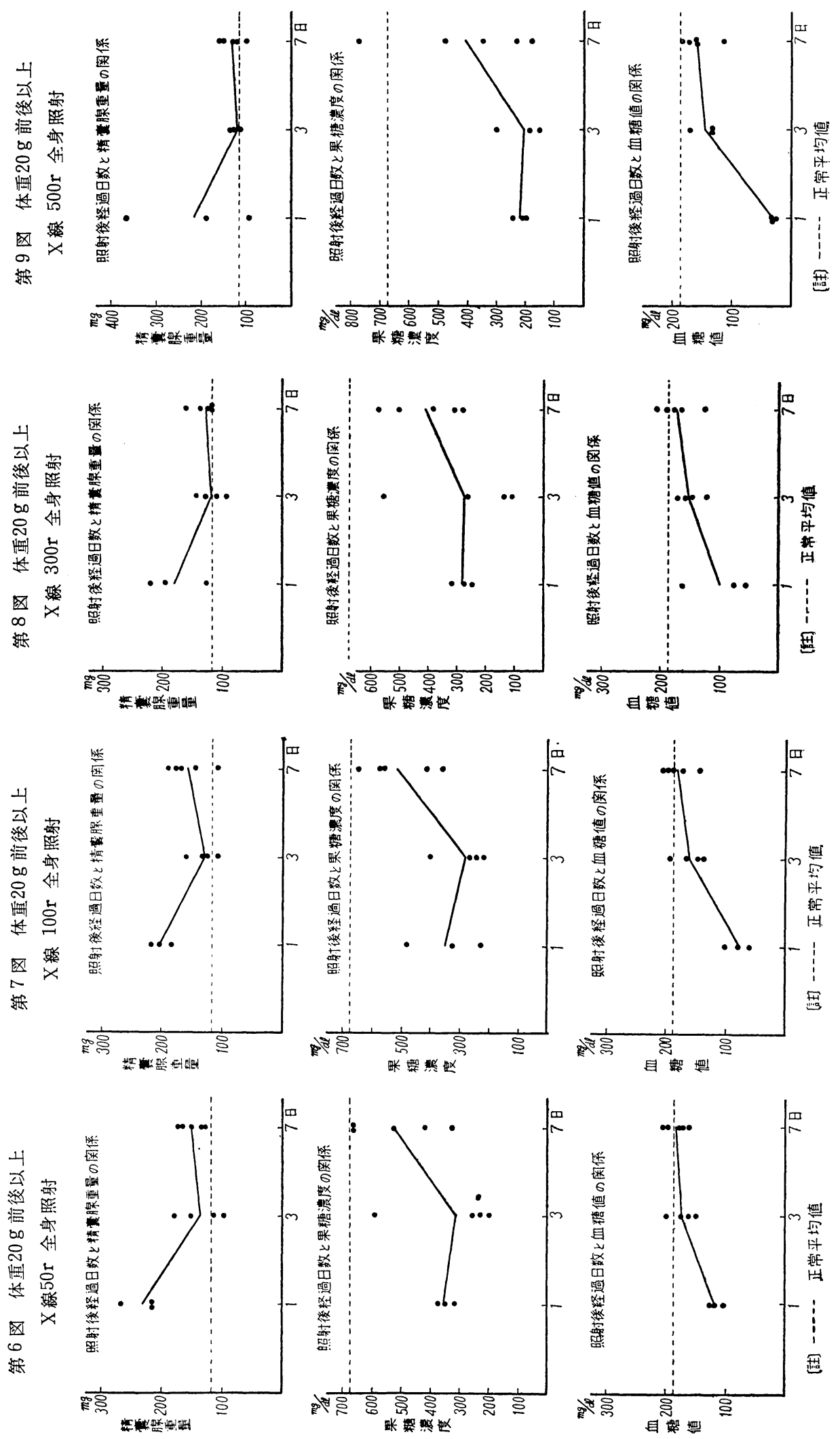
第 6 表 X 線辠丸照射 1 日後

\begin{tabular}{|c|c|c|c|c|c|}
\hline 昭射量 & 番号 & 体 重 & $\begin{array}{l}\text { 精霝腺 } \\
\text { 量 }\end{array}$ & $\begin{array}{ll}\text { 裹 } & \text { 糖 } \\
\text { 濃 } & \text { 度 }\end{array}$ & 血糖値 \\
\hline \multirow{6}{*}{$50 \mathrm{r}$} & 1 & 14.3 & 101 & 21 & 90 \\
\hline & 2 & 15.8 & 112 & 63 & 53 \\
\hline & 3 & 16.3 & 72 & 57 & 170 \\
\hline & 4 & 17.5 & 134 & 286 & 184 \\
\hline & 5 & 20.0 & 117 & 42 & 59 \\
\hline & 平均 & 16.8 & $\mid 107.2$ & 93.8 & 111.2 \\
\hline \multirow{6}{*}{$100 \mathrm{r}$} & 6 & 14.3 & 74 & \begin{tabular}{l|l}
26 \\
\end{tabular} & 122 \\
\hline & 7 & 14.8 & 101 & 76 & 147 \\
\hline & 8 & 15.6 & 80 & 84 & 160 \\
\hline & 9 & 16.3 & 162 & 110 & 160 \\
\hline & 10 & 17.3 & 120 & 84 & 101.5 \\
\hline & 平均 & 15.7 & $\mid \overline{107.4}$ & 76.0 & 138.1 \\
\hline \multirow{6}{*}{$300 \mathrm{r}$} & 11 & 13.8 & 69 & 63 & 139 \\
\hline & 12 & 14.3 & 96 & 64 & 122 \\
\hline & 13 & 14.3 & 120 & 57 & 140 \\
\hline & 14 & 15.3 & 97 & 51 & 158 \\
\hline & 15 & 19.6 & 110 & 294 & 197 \\
\hline & 平均 & 15.5 & $\mid 98.4$ & 105.8 & 151.2 \\
\hline \multirow{6}{*}{$500 \mathrm{r}$} & 16 & 12.3 & 76 & 21 & 66 \\
\hline & 17 & 14.3 & 94 & 51 & 188 \\
\hline & 1.8 & 14.3 & 123 & 42 & 228 \\
\hline & 19 & 15.3 & 101 & 20 & $\overline{124.5}$ \\
\hline & 20 & 19.5 & 175 & 210 & 227 \\
\hline & 平均 & 15.1 & $\mid 113.8$ & 68.8 & 166.7 \\
\hline
\end{tabular}

る各群について, その日数の経過による精囊腺重量, 精 囊腺内果糖濃度掞よび血糖值に及ぼす影響について調べ て見た．X線宰丸照射の日数の経過による影響を調べる 場合に，特に幼若マウスの箤丸への影響を見るために15 $\mathrm{g}$ 前後以下の体重の幼若マウスのみをとりあげた。

D） X線箤丸照射 $50 \mathrm{r}$

精囊腺重量は照射 1 日後は正常值を示すが, 3 日後は や>低値を示し，7日後では正常值に復している. 精囊 腺内果糖は照射 1 日後に著明に減少し, 3 日後は更に減 少し, 7 日後では正常值に恢復する. 血糖値は 1 日後は 低値を示すが日数の経過と共に正常に復す。

E） X線睪丸照射 $100 \mathrm{r}$

精囊腺重量は 3 日後にや>低值を示すが, 7 日後では 恢復する. 精䨋腺内果糖は 1 日後にすでに平均值の半值 を示し, 3 日後には更に低下し, 7 日後では正常值への 恢復の徴を示す. 血糖値は精囊腺内果糖と同様に 3 日目 に低值を示すが, 何れも正常値範囲内であつて, 殆んぞ 变化は見られない。
第10図 $\mathrm{X}$ 線䬓丸照射 1 日後
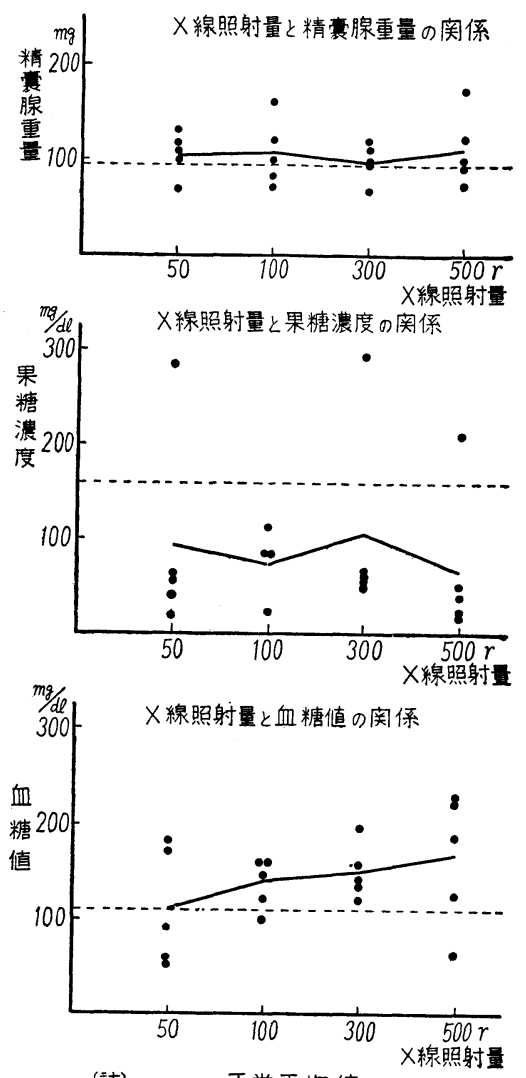

(註) ---.- 正常平均値

F） X線睪丸照射 $300 \mathrm{r}$

精囊腺重量は50r, 100r 照射の場合と同様に 3 日後に 低值を示すが, 7 日後には恢復する. 果糖濃度も亦50r, 100r 照射の場合と同じような傾向を示し, 血糖值は 1 日後, 3 日後はほぶ正常で, 7 日後はや〉高檤を示した。

G） X線寞丸照射 $500 \mathrm{r}$

精囊腺重量, 精囊腺内果糖濃度掞よび血糖値のいづれ もが 300r 照射の場合と全く同様の傾向を示した. だ゙ 精囊腺内果糖のみは 7 日後におりる恢復がや>退いよう である。

\section{IV 総括並びに考按}

精液果糖が等丸掞よび副性器の健否により支配される ことは先に教室の山村年或は $\mathrm{Mann}^{8)}$, 志田 ${ }^{9}$ 等の記載す るところであり,また血糖が精液果糖量飞密接な関係に あり, 精液果糖量が血糖值に比例して増減することも証 明されている8 .

こ〉に抢いて私は, 原子爆彈の放射能が, いかに性腺 
第 7 表 $X$ 線楓丸照射 3 日後

\begin{tabular}{|c|c|c|c|c|c|}
\hline 照射量 & 番号 & 体 重 & $\begin{array}{l}\text { 精霟腺 } \\
\text { 量 }\end{array}$ & $\begin{array}{ll}\text { 果 } & \text { 糖 } \\
\text { 濃 }\end{array}$ & 血糖值 \\
\hline \multirow{6}{*}{$50 \mathrm{r}$} & 1 & 14.3 & 59 & 17 & 125 \\
\hline & 2 & 15.0 & 63 & 19 & 114 \\
\hline & 3 & 19.8 & 78 & 300 & 110 \\
\hline & 4 & 21.0 & 111 & 118 & 193 \\
\hline & 5 & 21.3 & 127 & 101 & 114 \\
\hline & 平均 & 18.3 & 87.6 & 111.0 & 131.2 \\
\hline \multirow{6}{*}{$100 \mathrm{r}$} & 6 & 13.3 & 56 & 32 & 102 \\
\hline & 7 & 15.0 & 52 & 37 & 124.5 \\
\hline & 8 & 18.3 & 145 & 201 & 213 \\
\hline & 9 & 22.3 & 94 & 305 & 141 \\
\hline & 10 & 22.7 & 161 & 330 & 184 \\
\hline & 平均 & 18.3 & 101.6 & 181.0 & 152.9 \\
\hline \multirow{6}{*}{$300 \mathrm{r}$} & 11 & 13.3 & 43 & 22 & 139 \\
\hline & 12 & 14.3 & 54 & 29 & 131 \\
\hline & 13 & 20.3 & 73 & 211 & 133 \\
\hline & 14 & 20.8 & 114 & 110 & 188 \\
\hline & 15 & 24.8 & 120 & 400 & 139 \\
\hline & 平均 & 18.7 & 80.8 & 154.4 & 146.0 \\
\hline \multirow{6}{*}{$500 \mathrm{r}$} & 16 & 11.3 & 50 & 5 & 97 \\
\hline & 17 & 11.3 & 45 & 5.3 & 131 \\
\hline & 18 & 19.8 & 65 & 237 & 122 \\
\hline & 19 & 21.3 & 151 & 248 & 199 \\
\hline & 20 & 23.9 & 102 & 354 & 174 \\
\hline & 平均 & 17.5 & $\mid 82.6$ & $\overline{169.9}$ & 144.6 \\
\hline
\end{tabular}

および全身に作用し，その結果，血糖および精液果糖に 如何なる变化を来したかを調べるため, 原子爆彈被爆者 の精液果糖怙よび血糖値を測定すると共に，マウスを用 いて実驗的にX線を全身怙よび睪丸に夫タ照射し，それ らの精霊腺内果糖濃度掞よび血糖值に対する影響を実驗 した.

被爆者の精液果糖および血糖については, 原子爆彈被 爆以来13年を経過するが，今日な㧍被爆者の犠牲は後を た〉ず，その健康管理及び治療は重大な問題となつてお り, 現在においてもなお定期的に或は必要に應じて諸检 查が行われているが，乙れらの检査は主として造血蔵器 および末梢血液像灵: 対象としたものである.しかし性腺 および精子等，生殖機能に関しては被爆当時その影響に ついて2〜3の報告があるのみで3).4).5)., 最近その研究 報告を見ず，又精液果糖に関してはまだその報告に接し ない，私は少数例ではあるが被爆者の精液果糖測定を主 とする精液検査を行うと共に, 血糖值をも測定した。

被爆者は 38 才の 1 名を除く外怡何れも18才より28才ま
第11図 X線䔂丸照射 3 日後
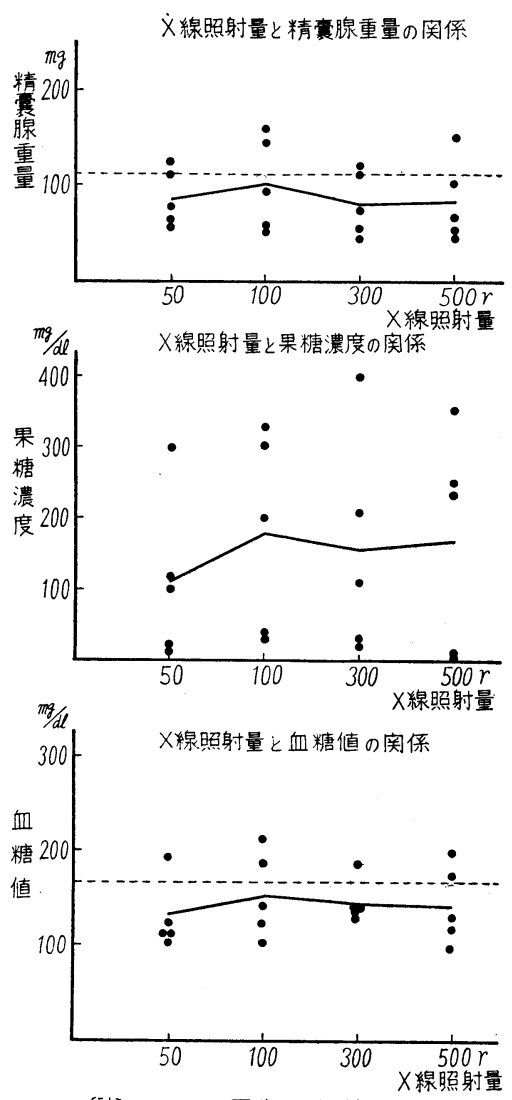

[註] ……正常平均値

での比較的若年者であり，乙れらの人々は被爆当時は小 兒期ないしは少年期のものであり, 放射線の影響も比較 的大きく, 又とれらの人々の将来に及涂す影響む重要て あると考えられる．しかし年令による原爆の影響冲認め られなかつた。

被爆年令による影響と共に, 被爆距離の遠近峺に重 大なる影響を行ぼすむのと考えられる。諸家の報告3),4). 5).7)・もまた被爆距離による影響について述べ, 被爆当時

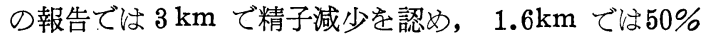
が不弤， $0.6 \mathrm{~km}$ 以内では全員不妊であると云い，末た $2,000 \mathrm{~m}$ 前後以内淩一過性去勢, $1500 \mathrm{~m}$ 以内では永久不 妊になる可能性があると述べているが, その 2 年後の報 告では著明に恢復の傾向を認めている。 また廣島原爆障 害研究会 ${ }^{7)}$ の報告の如く, ただ單に被爆距離のみならず 被爆時の情況, 即ち主として遮蔽物の有無及びその程度 により，熱線のみならず $\gamma$ 線及び中性子による障害に大 
第 8 表 X線鼻丸照射 7 日後

\begin{tabular}{|c|c|c|c|c|c|}
\hline 照射量 & 番号 & 体 重 & $\begin{array}{l}\text { 精需腺 } \\
\text { 量 }\end{array}$ & $\begin{array}{ll}\text { 果 } & \text { 糖 } \\
\text { 濃 }\end{array}$ & 血糖値 \\
\hline \multirow{7}{*}{$50 \mathrm{r}$} & 1 & 14.5 & 102 & 163 & 135 \\
\hline & 2 & 14.8 & 113 & 182 & 151 \\
\hline & 3 & 20.7 & 114 & 286 & 143 \\
\hline & 4 & 23.6 & 137 & 608 & 160 \\
\hline & 5 & 26.3 & 137 & 121 & 141 \\
\hline & 6 & 27.8 & 156 & 520 & 213 \\
\hline & 平均 & 21.3 & $\overline{126.5}$ & $\overline{313.3}$ & 157.2 \\
\hline \multirow{6}{*}{$100 \mathrm{r}$} & 7 & 15.3 & 105 & 98 & 135 \\
\hline & 8 & 15.8 & 89 & 121 & 147 \\
\hline & 9 & 23.6 & 122 & 296 & 147 \\
\hline & 10 & 24.8 & 136 & 708 & 170 \\
\hline & 11 & 25.0 & 133 & 98 & 139 \\
\hline & 平均 & 20.9 & 117.0 & 264.2 & 147.6 \\
\hline \multirow{7}{*}{$300 \mathrm{r}$} & 12 & 12.8 & 99 & 140 & 174 \\
\hline & 13 & 15.6 & 87 & 129 & 148 \\
\hline & 14 & 19.3 & 107 & 224 & 131 \\
\hline & 15 & 20.2 & 147 & 173 & 151 \\
\hline & 16 & 20.3 & 139 & 370 & 176.5 \\
\hline & 17 & 27.8 & 134 & 143 & 174 \\
\hline & 平均 & 19.3 & 118.8 & 196.5 & 159.1 \\
\hline \multirow{7}{*}{$500 \mathrm{r}$} & 18 & 15.8 & 96 & 64 & 147 \\
\hline & 19 & 16.0 & 94 & 104 & 164 \\
\hline & 20 & 20.3 & 94 & 572 & 181.5 \\
\hline & 21 & 21.0 & 124 & 230 & 176.5 \\
\hline & 22 & 23.9 & 129 & 201 & 218 \\
\hline & 23 & 24.8 & 197 & 489 & 129 \\
\hline & 平均 & 20.3 & $\mid 122.3$ & 276.7 & 169.3 \\
\hline
\end{tabular}

なる相違があるものと考えられる．とのような條件の加 わるためか，被爆距離が短いものが最も影響が大きかつ たかと云うにそうばかりではなく，精液果糖量に減少を 認める 4 例のうち, その 3 例は夫く $1.7 \mathrm{~km}, 1.8 \mathrm{~km}, 2.0$ $\mathrm{km}$ こいずれも比較的近距離で被爆しているが, 他の 1 例怡 $3 \mathrm{~km}$ の所で被爆している. 又一方比較的近距離の $1.5 \mathrm{~km} \sim 2.0 \mathrm{~km}$ 所で被爆せるものでも全く正常值を 示している. しかし被爆距離 $2.0 \mathrm{~km}$ 以内の被爆者の方 に障害を認めるものが多いように思われる。

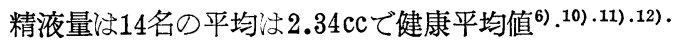
13)·よりや>低值を示しているが, 各人について見ると直 接被爆距離の影響によるものとは考えられない．また被 爆による不妊症の問題について考えて見るに, 精子数お よび精液量より判断して不妊症 ${ }^{33.47 .6) .99 .14) ~}$ 已考えられる すの 5 例学数えるが, その中 3 例は未婚者であり, 他の
第12因 $\mathrm{X}$ 線辠丸照射 7 日後
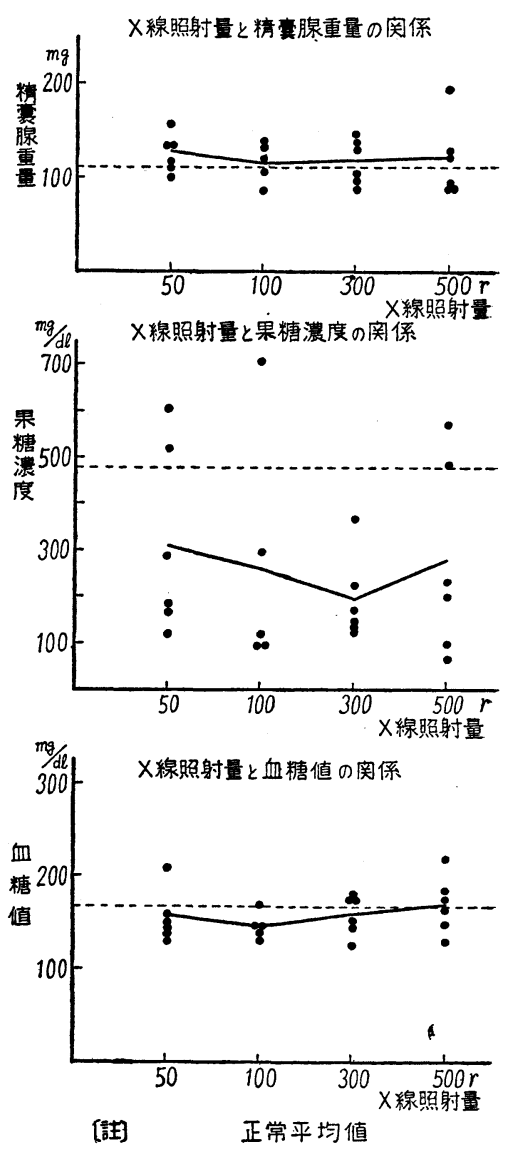

2 例は既婚で不妊を訴えている.

精液果糖濃度は平均 $243.8 \mathrm{mg} / \mathrm{dl}$ でほ心゙正常值(6).8).99. 10).11).12).13).14).，5例に低值を認め, その中 $134 \mathrm{mg} / \mathrm{dl}$ を 示すものは一應除外するとしても，4例に明らかに果糖 濃度の低值を認める. この中の 1 例は第 3 例の 27 才，既 婚, 被爆距離 $1.7 \mathrm{~km}$, 子供なし, 精子数 0 , 精液量 1.3 $\mathrm{cc}$, 果糖量 $27 \mathrm{mg} / \mathrm{dl}$, 血糖值 $59 \mathrm{mg} / \mathrm{dl}$ であり, 又もう 1 例法 第14例の28才, 未婚, 被爆距離 $3.0 \mathrm{~km}$, 精子数 $33 \times 10^{6}$, 精液量 $1.0 \mathrm{cc}$, 果糖量 $6 \mathrm{mg} / \mathrm{dl}$, 血糖値 $70 \mathrm{mg} / \mathrm{dl}$ であつて, 明らかに变化を認め, 又他の 2 例に抎いても夫第 5 例, 第 7 例の如く果糖量のみならず夫々精液量, 血糖值 にも変化を認めた。しかしてれが原爆の影響によるもの か否かについては俄かに断定できない。

血糖值については放射線による影響としては，X線照 射の場合の報告には接するが15.116)·原爆の影響に関して 
第13図 体重 $15 \mathrm{~g}$ 前後以下

$\mathrm{X}$ 線 $50 \mathrm{r}$ 章丸照射
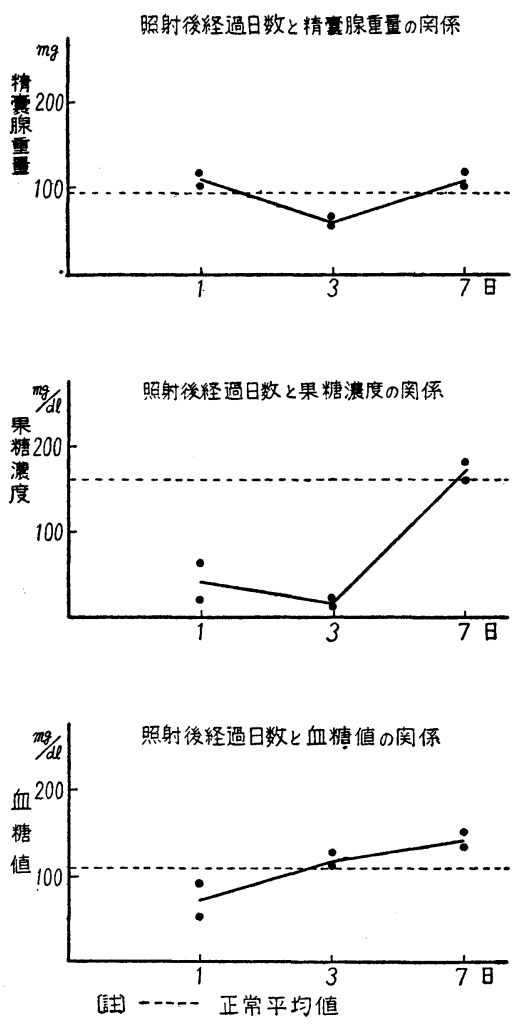

は適当なものに接し得なかつた。被爆者中 3 例に低血糖 を認めたが，そのいずれもが精液果糖量は非常に低值を 示し, 血糖値と果糖濃度との平行関係を示すと共に, と れら患者に何等かの障害のあるととを示している.

以上原子爆彈被爆者の精液果糖, 精夜量, 精子数扮よ び血糖值について考察を加えたが，次に実驗的にX線を 種々の條件でマウスに照射し, その精囊腺内果糖, 血糖 および精囊腺重量に及汸す影響に関して述べる.

先づ体重15〜24 gの健常マウス10匹を检したが，1側 精囊腺重量は.72〜 147mgの間にあり, その含有せる果糖 量は 140〜 978mg/dlの間にあり, 精囊腺重量と果桾濃度 は脑ぶ比例するととを認めた。血糖值は86〜 210.5mg/d で, 果糖量が多いものは血糖値も高值を示すようにう かがわれる. 比較的幼若な, 体重13.3〜16 gのマウスで は, 精襄腺内果糖濃度法 $42 \sim 398 \mathrm{mg} / \mathrm{dl}$, 血糖值は86〜 179 mg/dlであつた。との場合山村6)・はエーテル杯醉は精液 果糖量には影響を及洼さないと述べているが，血糖値に ついては，エーテル麻醉は一般に血糖上昇を来すととが
第14図 体重 $15 \mathrm{~g}$ 前後以下

$\mathrm{X}$ 線 100r 拿丸炤射
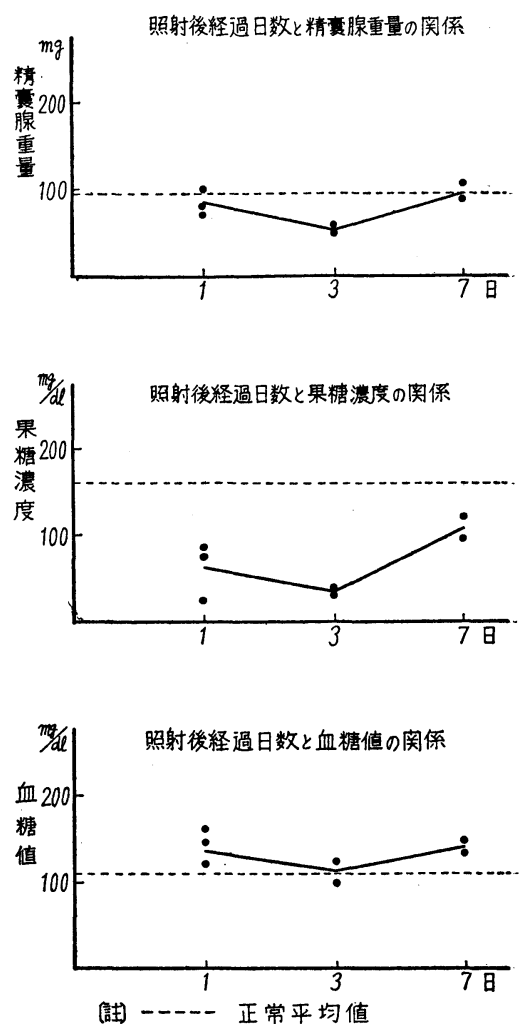

認められている ${ }^{19)}$, 又手迶に関しては, 果糖濃度には影 響はないというが，血糖值に関しては，エーテル麻醉と 同様にその上昇を来すととは衆知の事実である.しかし て血糖上昇は手術の大小により異り，特に大手術の場合

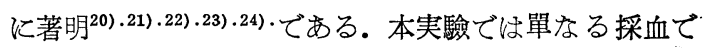
あつて手術的侵襲とは考えられないが，私の実驗に括い て，マウスの血糖值がやや高值を示しているとすれば， これは上記の如き理由によるものではないかと考えてい， る.

次にマウスに対するX線照射の影響については, X線: 全身照射の場合として, 体重13.5 28.3 g の健常マウス にX線を夫々50r，100r，300r 及び 500r 照射し, 夫

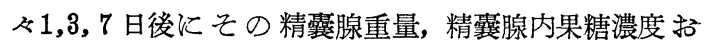
よび血糖值を測定したのであるが, 精囊腺重量はX線照 射後の経過日数による変化はないが, 果糖濃度扣よび血 糖値は, X線照射量の増加につれて次第に低下する傾向 を示し, その傾向は照射後日数の経過につれて軽度とな る.また果糖濃度に比して血糖值はX線量による影響が。 
第15図体重15 g 前後以下

$\mathrm{X}$ 線 $300 \mathrm{r}$ 粹丸照射
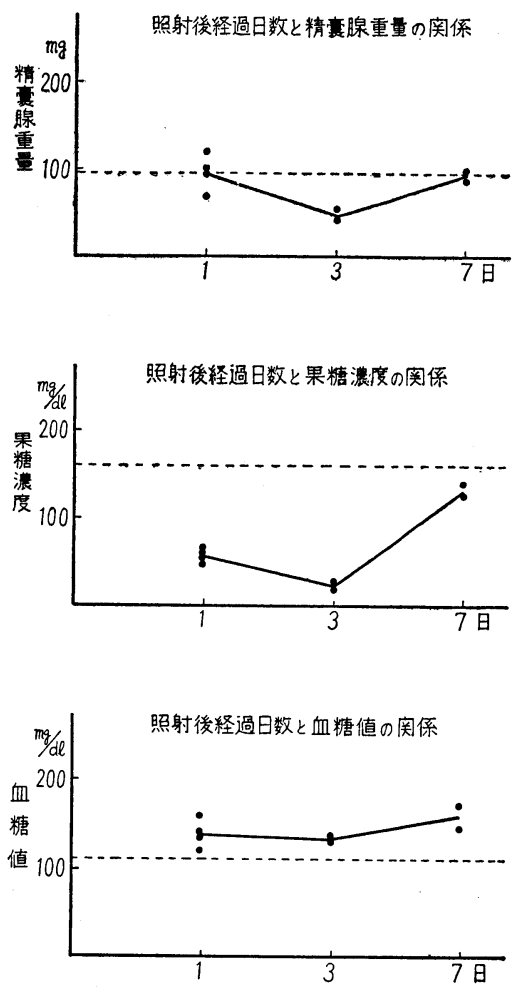

(註) - - - - は正常平均値

非常に少い.

家鬼，海猽，犬等の上腹部X線照射後には過血糖を来 すと云うが ${ }^{15)}$, 全身照射により糖代謝に関係のある膵 臟, 肝臓, 腦等にX線が夫々刺激的或は破壊的火㗢き, その作用は種くであり, また勝 ${ }^{16)}$, 中村等 ${ }^{25)}$ は人体X線 全身照射は血糖値に著変を及淁さないと云つている.

本実驗に掞いては，X線全身照射直後は或は過血糖を 示したかも知れないが, 24時間後では既に低值を示した. しかし 3 日後及び 7 日後では正常值を示し, 何等X線の 影響を認めることは出来ない。

精囊腺はX線照射後短時日のためか, その重量の変化 は殆んぞ認められなかつたが，果糖濃度はX線による精 囊腺及び睪丸の障害のためか，または低血糖によるため に低值を示したものと思われる。

次に $20 \mathrm{~g}$ 前後以上のマウスにつきX線照射後の経過日 数による影響を調べるため, 夫々 $50 \mathrm{r}, 100 \mathrm{r}, 300 \mathrm{r}$ 及 び 500rを全身に照射し, 経過日数による精营腺重量, 精囊腺内果糖濃度孔よび血糖值の变化を見るに, 精囊腺
第16図 体重15 g 前後以下

$\mathrm{X}$ 線 500r 辠丸炤射
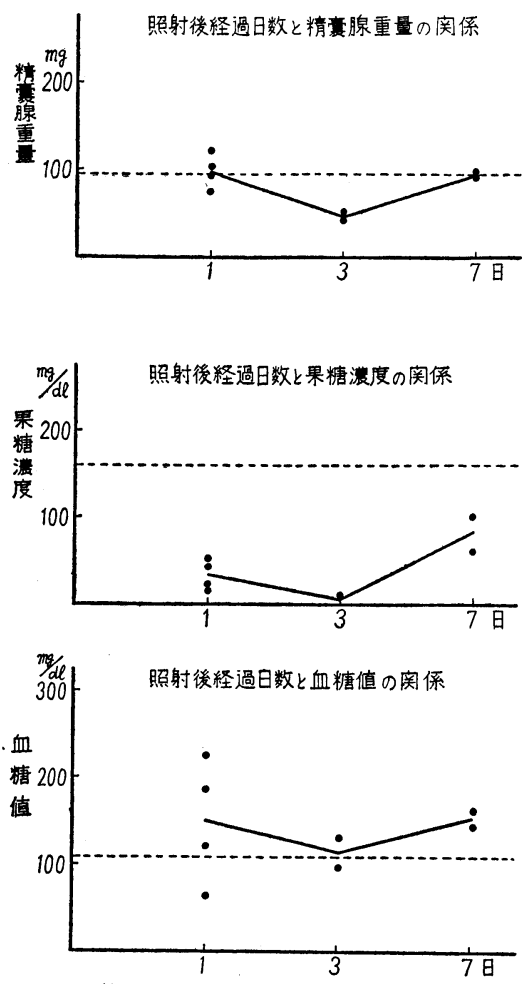

(註) -..-・时正常平均値

重量は正常範囲内であるが，3 日後掞よび 7 日後はや〉 減少している，精囊腺内果糖量はX $\mathrm{X}$ 線照射により，照射 X線量の如何にかつわらず低值を示すが，照射後 1 日で すでに低下し，3 日後は最低を示すが，7 日後には既に 殆んぞ健常平均値に復している. 血糖値は，1 日後に最 低を示し，3 日後には既に恢復の徴あり，7 日後では殆 んど健常平均值へ帰る. 即与, 果糖は血糖恢復に退れて 恢復し, 血糖より果糖への轉化には或程度の時間を必要 とするもののようである.

X線箤丸照射について眺めると，X線等丸照射の場合 に，その照射 X線量の大小による影響を調べるために， 体重11.3 27.8 g の健常マウスにX線を夫々50r, 100r, 300r 及び 500 r 照射し，夫々 $1,3,7$ 日後に精囊腺重 量, 精襄腺内果糖量扝よび血糖值を測定した。精囊腺 重量はX線照射 3 日後に僅に低值を示す外に, 照射 X線 量による影響は殆んで認められず，精囊腺内果糖濃度は $\mathrm{X}$ 線照射後1,3，7 日の何れに拀いても健常平均値より低 值を示すが，照射X線量による影響は全く不定である。 血糖值も果糖濃度と同様に一定の傾向は見られなかつた 
が, ほぶ正常範囲内で, 果糖濃度との関係に括いて, や >比例関係にあることを思わしめた。

次にX線照射後の経過日数による影響であるが，精囊 腺重量はX線量によらず，3 日後には低下し，7日で大 体照射後 1 日の重量に帰る. 果糖濃度は 1 日後より低值 を示すが, 3 日後浪低となり，7 日後では健常平均值 に帰る傾向を示すが，500r 照射群ではその恢復がや> 惡い，血糖值も果糖濃度に臣ぶ平行関係を示すが，その 变動する值の範囲は果糖濃度よりも少い。

X線を皿丸部に照射するととにより, 垶丸機能の荒廢 を来し, 精液果糖に対して大なる影響を来すものと考え たが, 認むべき一定の傾向は認められず, 精液果糖の及 ならず血桾に抬いてもむしろ全身への照射の方が影響が 大きく明らかであつた。

血糖值に捛いては全身照射の場合には, 果糖は血糖恢 復に退れて恢復したが, 粹丸照射の場合にははミ゙平行し

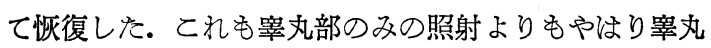
部をも含めた全身への照射の方が，マウスに対する影響 が大きかつた爲であると考えられる。

以上，原爆被爆者に抢ける精液所見と，マウスに対す るX線照射実驗を考察すると, そのうけた放射能によつ ては, 精子形成が或程度認められても, 果糖濃度の低下 する例むあり, 案外この方面は等閑に附されている傾向 があることよりして, 被爆者はもとより, 放射能に曝さ れている限り, この方面の注意快疎かにすべきでないこ そを申したい。

\section{V 結 論}

放射線の精液果糖亚びに血糖值に及ぼす影響を，原爆 被爆者及びX線を照射せるマウスにつき检索せる結果, 次の結論を得た。

1. 原爆被爆者14名中 5 名に精液果糖量の低下を認 め, その内 3 名注血楉値も低下していた.

2. マウスの全身にX線を照射すれば, その照射量に より, 精囊腺重量には殆んど変化は認めないが, 精囊腺 内果糖濃度掞よび血糖值は, 照射X線量の增加につれて 次第に低下し，その傾向は日数の経過につれて軽度とな り，7 日後には殆んど正常值に帰る.

3. マウスの箤丸部にX線を照射すれば，X線照射量
により精㖶腺重量は殆んぞ変化を見ず, 果糖濃度は一般 に低值を示すが, 一定の傾向はなかつた. 然し7日後に は正常值に帰る傾向定示した. 血糖值は 3 日後にや>低 值を示すのみで，X線による影響は殆んで認められなか つた.

稿を終るに臨み, 恩師大村教授の御指導と御校閲を深 謝すると共に, 御協力下さつた広島市民病院院長甲斐太 郎博士, 藤井浩博士及び放射線科の皆様に感謝する。

\section{主要交献}

1) 都築 : 綜合医学, 14, 493, 1957.

2) 渡辺：綜合医学, 14, 924, 1957.

3）大越：原子爆弾災害調査報告, 第 1 分册, 720 , 1953.

4）石川：原子爆弾災害調査報告, 第 1 分册, 724 , 1953.

5）石川：原子爆弾炎害調查報告, 第 1 分册, 727 , 1953.

6) 山村：岡医誌，69, (1)2969(2)2985, 1957.

7) 広島原爆障害研究会: 日本医師会雑誌, 39,674 扣よび802， 1958.

8） T. Mann : 精液の生化学, 三共出版, $1 \sim 83$ 拧 よび 135〜160, (1956).

9）志田：男性ホルモンと臨床, 医茵薬出版, (1953).

10）三矢：日泌尿会誌， 48, 419, 1957.

11）赤堀: 第 1 回西日本不妊学会 (抄), (1958).

12）瀬川：日泌尿会誌, $48,869,1957$.

13）外塚：日泌尿会誌, $43,215,1952$.

14）西村：臨床皮泌，7,835, 1953.

15) Paul Lazarus: Handbuch der gesamten Strahlenheilkunde 1 Band. 435, (1928).

16）勝：第43回九州沖繩医学会会誌, (抄) 107, (1943).

17) A.W. Oughterson \& S. Warren: Medical Effects of the Atomic Bonb in Japan, p. 298, 318, (1949).

18) A.A. Liebow, S. Warren \& E. DE Coursey: Am. J. Path, 25, 853 1027, 1949.

19）丘中：長崎医学会雑誌, 30, $1035,1955$.

20）浅岡：日産婦会誌, 7,1619, 1955.

21）渡辺：日外会誌, $\mathbf{5 6}, \mathbf{1 1 2 6}, 1955$.

22）山下：医療, 4, 103, 1950.

23) 山口: 名古屋市立大医学会雑誌, 2, 17, 1951.

24) 八田：熊本医学会雑誌, 28, 特集号203, 1954.

25）中村：共済医報，6,270，(1937). 抄 